\title{
THE DOCTRINE OF EXHAUSTION OF UNION REMEDIES
}

\section{FRANK J. MONTEMURO, JR.*}

The doctrine that an expelled or suspended member of a labor union must first exhaust his remedies within the union before obtaining judicial relief, presents a problem of equating two apparently contradictory interests, (1) the protection of the member's civil rights and (2) the necessity of group solidarity for the union. It is difficult to balance the scales. To give too much weight to one or the other of the two interests involved can be very detrimental either to the individual member or to the union.

If the number of disciplinary abuses is viewed merely in its ratio to the total number of union members, the problem would seem to be of little significance. ${ }^{1}$ However, we are concerned here with an individual's civil rights, and any such proportional analysis must be cast aside. To state a truism, there have been well-known cases of disciplinary abuse by unions, ${ }^{2}$ and many others never come to light because the workers lack the means of publicity, or more probably, because the workers are not financially capable of obtaining court relief.

A union must have some power to relieve itself of discordant elements in order that it may function as a unit; therefore, it has the right to provide by its constitution and bylaws for expulsion of members violating the reasonable

* 3rd year law student, Duke; Temple 1946-1949.

1 ". . . it should be recognized that the disciplinary power has its own practical limitations. Since the union's effectiveness is based largely on the degree to which it controls the avallable labor supply, expulsions tend to weaken the union. If large numbers are expelied, it is likely that they will be driven into the arms of a rival union." Summers, Disciplinary Powers of Unions, 3 IND. \& LAB. REd. REv. 487 (1946).

2 Even the very democratic International Typographical Union provides that, "Any member belonging to, or aiding in the formation of, any organization dual to the I.T.U. may be summarily expelled by the Executive Council ... when it is deemed necessary to protect the jurisdiction of the I.T.U." Shister, Trade Union Government-A. Frormal Analysis, 60 Q. J. EcoN. 78, at 95, n. $3(1945 / 46)$. (Emphasis added). 
provisions of the constitution or by-laws. ${ }^{3}$ However, should this power permit the union to dispense with notice, written charges, hearing, confrontation of the accusers, cross-examination and other requisites of procedural due process? Should it preclude freedom to criticize and oppose union officials?

The purpose of this article is to show: (1) some situations where the courts have given union members a green light to seek judicial relief without first exhausting all remedies provided for by the union constitution, and (2) some of the courts' reasons for permitting this deviation from the general rule which requires exhaustion of union remedies before judicial relief is granted.

\section{The General Rule and the Theory On Which It Is Based}

The reports are replete with decisions stating the rule that judicial remedies are not available to a member wrongfully expelled or suspended from a union unless he has first exhausted such remedies as may exist within the union. ${ }^{4}$

Borrowing from the law of other voluntary asosciations, ${ }^{5}$ it has been held that the constitution and by-laws of a union constitute a contract between its members, and that their rights and duties, both as between themselves and in their relation to the association, in all matters affecting its internal government and management, are measured by the terms of such contract. ${ }^{\circ}$

The application of the contract theory to all voluntary organizations, including labor unions, has been severely

\footnotetext{
s Barnhart v. United Auto., Aircraft, Agriculture Implement Workers of America (UAW-CIO), 12 N.J. Super. 147, 79 A.2d 88 (1951).

- See, e.g., Porth v. Local Union 201, United Brotherhood of Carpenters and Joiners of America, 171 Kan. 177, 231 P.2d 252 (1951); Donahue v. Keunedy, 99 N.E.2d 155 (Mass. 1951); Cromwell v. Morrin, 91 N.Y.S.2d 176 (Sup.Ct. 1949); O'Grady v. McFetridge, 334 IIl. App. 390, 79 N.E.2d 644 (1949).

- See Greenwood v. Building Trades Council, 71 Cal. App. 159, 233 Pac. 823 (1925).

- See cases cited, supra note 4.
} 
criticized. ${ }^{7}$ Carrying this theory to its logical conclusion, a member joining a labor union would have to abide by a constitutional clause providing for immediate expulsion without trial or notice. Fortunately, the courts, though they talk "contract," have avoided this logical but unjust result by drawing many and sundry exceptions to the general rule.

Some unions have fairly detailed standards of fair play and procedural due process. ${ }^{8}$ By strict application of the contract theory, a member agrees to these procedural standards in the constitution or by-laws when he accepts membership, and it would seem he would be bound by a decision reached on the basis of such standards. The final appeal body ultimately must decide whether or not union law has been complied with. If the union's appeal body decides that union law has been complied with, should a court review the disciplinary proceedings de novo, i.e., the union's decision as to its own rules? It has been held that a court will not review the merits of a decision by a union tribunal or its interpretation of valid union rules; under this rule, review is confined to the question of whether the member received a fair trial upon proper and substantial evidence. ${ }^{9}$ However, it has been pointed out that even this

\footnotetext{
7 Professor Chafee points out that the member's contract is often a legal fiction which prevents the courts from considering ... genulne reasons for and against relief. Chafee, Internal Affairs of Associations Not For Profit, 43 HARv. L. REv. 993, 1007 (1930). See, also, Shister, op. cit. supra note 2 , at 91 , n.6.

8 Union disciplinary procedures usually provide for flling of speciflc charges in writing, membership referral of charges to a trial committee, timely notice of charges to the accused, and a bearing thereon. Fach side may select counsel from among union members, and-some unions permit members of the trial committee to be challenged. The accused has the right to present evidence and to cross-examine prosecution witnesses. A trial committee verdict-majority vote usually suffices-is generally no more tban a recommendation to the next local meeting at which the accused must be present. If a verdict of guilty is approved a penalty of a flne or reprimand usually requires a majority vote, while a two-thirds or three-fourths vote is required for suspension or expulsion. Taft, Judicial Procedure in Labor Unions, 59 Q. J. Econ. 381, 384 (1945).

- Local Union No. 57, Brotherhood of Painters, Decorators and Paperhangers of America v. Boyd, 245 Ala. 227, 234, 16 So.2d 705, 711 (1944). Contra, Gordon v. Tomei, 144 Pa. Super. 449, 446, 19 A.2d 588,
} 
limited review permits courts to supplement, modify or disregard the consensual elements of the contractual relation between the member and the union. ${ }^{10}$

The fallacies of the contract theory are apparent. Nevextheless the courts still apply it in requiring a disciplined member to exhaust his remedies within the union before judicial relief will be granted. The reason for this refusal to give up the contract theory may be due to a justifiable fear of overburdening an already unwieldy court docket. Whatever the reason for the refusal to abandon the contract theory, it would not seem to justify acquiescence in a transgression of the civil rights of a union member. If the judiciary cannot resolve the dilemma, the legislative department should..$^{11}$

\section{Judicial Bases for Intervention}

Assuming application of the contract theory to be unsound, the courts are at least consistent in its application. Thus it has been consistently held that if disciplinary action against a member is not in accordance with the "contract," the rights of the member have been violated, and he may seek relief in the courts. In such a case, the member is not required to exhaust his remedies within the union. ${ }^{12}$

Another basis for judicial intervention is where a member's property rights are conceived to have been abridged. Conversely, a philosophic determination that "property rights" are not involved would be an independent ground for

596 (1941) (courts must make their own interpretations of union rules and legal regulations of members).

${ }^{10}$ CrafeE, op. cit, supra note 7, at 1014.

11 In Massachusetts an employee expelled from a union may appeal to a State Labor Relations Commission before he is discharged from his employment under a union-security contract. The Commission may order a union, in the union's discretion, to restore the employee to membership, or to refrain from seeking his discharge. Mass. Acts c. 657, Sections 1, 2, 6 (1947) amending MASs. GeN'L Laws c. 150A (1932). See the discussion of the ineffectiveness of state regulatory statutes in Summers, Legal Limitations on Jnion Discipline, 64 Harv. L. REv. 1049, 1056 (1951).

12 See, e.g., Polin v. Kaplan, 257 N.Y. 277, 177 N.E. 833 (1931); Krause v. Sanders, 66 Misc. 601, 122 N.Y.S. 54 (Sup.Ct. 1910), aff'd without opinion, 143 App. Div. 941, 127 N.Y.S. 1128 (1st Dep't. 1911). 
denial of judicial relief. Today virtually all courts recognize the right to a job and interests in benefit funds as property rights.13 Seniority rights have been called contract rights in the past, but the tendency is to regard them as "property."14 Death benefits and benefits for physical incapacity, ${ }^{15}$ the benefit of collective bargaining, ${ }^{16}$ a member's enforceable interest in union elections and an accounting of union funds, ${ }^{17}$ and membership itself, ${ }^{18}$ have been called property rights.

It is apparent that the property theory affords little relief to a member who has not been expelled but only suspendedfor the property theory is, in most cases, applied only where dollar values of membership are involved. It has been stated that membership in a union should confer the right to full participation in all union activities and should include the right to attend union meetings in which policies are determined, the right to debate those policies, the right to vote on them, and the right to vote for union officers. ${ }^{10}$ At best, the property theory is an inadequate alternative where a strict adherence to the contract theory would deprive a suspended member of outside relief.

The courts have sometimes been able to hold on to the contract and property theories, and at the same time intervene whenever they thought a particular type of conduct should be privileged. This of course is but an ostensible solution to the problem-a mere escape through the horns of the dilemma. The courts have no affirmative standards to go by and they are harassed by fine distinctions and vagaries.

23 De Mille 7. A.F.I. Radio Artists, Los Angeles Local, 31 Cal.2d 139, 187 P.2d 769 (1947), cert. denied, 333 U.S. 876 (1947).

${ }^{14}$ See note, 142 A.L.R. 1055, 1060-61 (1943).

15 Heasley $\nabla$. Operative Plasterers and Cement Finisher's Int'l. Ass'n., 324 Pa. 257, 188 A. 206 (1936).

Io Obergfell 7. Green, 29 F. Supp. 589, 591 (D. D. C. 1939).

17 Dusing v. Nuzzo, 177 Misc. 35, 29 N.Y.S.2d 882 (Sup.Ct. 1941).

18 Fleming v. Moving Picture Machine Operators, 124 N.J.Eq. 269, 1 A.2d 386 (1938) (plaintiff reinstated and union ordered to pay back wages).

10 Summers, op. cit. supra note 11, at 1056.

20 For a criticism of the many exceptions engrafted onto the exhaus. tion rule, see Witmer, Civil Liberties and the Trade Union, 50 Yale 


\section{Specific Exceptions to the Rule That a Hember Irust First Exhaust His Remedies Within the Union Before He Can Get Judicial Relief}

It has been suggested that there have been so many exceptions grafted onto the general rule that it itself is now the exception. ${ }^{20}$ Most union constitutions provide procedural machinery with original and appellate jurisdiction and the machinery so provided is very similar among the different unions. ${ }^{21}$ But the courts have often allowed an expelled or suspended member to bypass this procedural machinery. For example, the courts have refused to require a member to exhaust his remedies within the union when the union tribunal lacked jurisdiction, ${ }^{22}$ when the member had no notice of the charges or was otherwise denied a fair hearing, ${ }^{23}$ when the member was punished for offenses not prohibited by the constitution or prohibited contrary to public policy, ${ }^{24}$ and when there existed a variety of other

L.J. 621, 630 (1941). Professor Summers has described it as a "myth." Summers, op. cit. supra note 11, at 1086.

21 Shister, op. cit. supra note 2, at 94.

$\cong$ Nissen v. International Brotherhood of Teamsters, Chauffeurs, Stablemen \& Felpers of America, 229 Iowa 1028, 1042, 295 N.W. 858, 866 (1941) (exhaustion required however, if union constitution expressly requires it); Gaestel v. Brotherhood of Painters, Decorators and Paperhangers, 120 N.J.Eq. 358, 185 Atl. 36 (1936); Gersh v. Ross, 238 App. Div. 552, 265 N.Y.S. 459 (1933); Local No. 7, B.M.P.I.U. v. Bowen, 278 Fed. 271 (S.D. Texas 1922).

${ }^{23}$ Washington Local Lodge No. $104 \mathrm{v}$. International Brotherhood of Boilermakers, 33 Wash.2d 1, 203 P.2d 1019 (1949) (member also has right to cross-examine); Armant v. Cannon Employee's Ass'n., 11 L.R. R.M. 572 (Cal.Super.Ct. 1942); Kennedy v. Schroeder, 10 L.R.R.M. 694 (N.Y.Sup.Ct. 1942) ; Heasley v. Operative Plasterers and Cement Finisher's Int'l. Ass'n., 324 Pa. 257, 188 Atl. 206 (1936). But cf. Janow v. Grad, 5 L.R.R.M. 952, 954 (N.Y.Sup.Ct. 1939) (expelled member of local union is not entitled to reinstatement on theory that he was not tried in accordance with its rules, where he was tried in accordance with rules of its parent body).

2" Schrank v. Brown, 22 L.R.R.M. 2227 (N.Y.Sup.Ct. 1948) (fair criticism of union officers is the right of union members and provision of union constitution suppressing protests of members against actions by their officers which the members regarded as improper would be illegal and unenforceable); Morgan v. Local 1150, United Electrical, Radio and Machine Workers of America, 16 L.R.R.M. 720 (Iil.Super. Ct. 1945) (expulsion of union member for opposing union's political activity was illegal). 
procedural irregularities. ${ }^{25}$

Another exception to the general rule of exhaustion has been recognized when further appeal by the expelled or suspended member would have been futile, vain or excessively delayed. ${ }^{26}$ There is conflict of opinion as to whether a member should be afforded judicial relief on the ground that his appeal within the union would be excessively delayed. However, it is apparent that since a decision of a lower body often remains in force until reversed by the convention, a long interval between conventions may frequently inflict undue hardships on members. ${ }^{27}$ Some of these hardships include loss of work where there is a union security clause in effect, loss of the right to attend meetings and help formulate union policy, and the loss of death and sick benefits. Where there is a showing of malice, bad faith or prejudice

$\approx$ Loney v. Wilson Storage and Transfer Co., 14 L.R.R.M. 896 (S.Dak.Cir.Ct. 1949) (appeal procedure so indefinite as to be invalid under state law which provides that contracts restricting enforcement of rights through legal proceedings are void); Chew v. Manhattan Laundries, Incorp., 14 L.R.R.M. 686 (N.J.Ct. Err. \& App. 1944) (union members had not been furnished copy of constitution and by-laws prior to suspension).

2o Local Union No. 57, Brotherhood of Painters, Decorators and Paperhangers of America v. Boyd, 245 Ala. 227, 16 So.2d 705 (1944) (general executive board which was to review his appeal, would not meet for some time and in a distant city); Reilly $v$. Hogan, 32 N.Y.S.2d 864 (Sup.Ct. 1942), aff'd without opinion, 264 App. Div. 855, 36 N.Y.S.2d 423 (1st Dep't. 1942) (convention of international union to which an appeal might have been taken was approximately a year away); Heasley v. Operative Plasterers \& Cement Finishers Int'1. Ass'n., 324 Pa. 257, 188 Atl. 206 (1936) (no final determination could have been made until after the expiration of plaintiff's guspension); Lo Bianco v. Crushing, 115 N.J.Eq. 558, 171 Atl. 778 (1934) (because of prejudice it would have been useless to pursue these rememdies within the union); Corregan v. Hay, 94 App. Div. 71, 87 N.Y.S. 956 (4th Dep't. 1904) (session of the union court at which the plaintiff's appeal would be heard would be held in a city many hundreds of miles distant from the plaintiff's residence). But cf. Snay v. Lovely, 276 Mass. 159, 176 N.E. 791 (1931) (the fact that the convention did not assemble uutil a year or more after the suspension of the member and then in a city outside of the commonwealth in which the member has resided did not affect the rule of exhaustion).

27 Professor Shister observed that in 1945, 39 unions held conventions without exception every year, 44 unions every 2 years, 8 unions every 3 years, 18 unions every 4 years and 7 unions every 5 years. Shister, op. cit. supra note 2,91 at n.6. 
of union authorities, ${ }^{28}$ or where there is a total absence of provisions for effective internal remedy, ${ }^{29}$ the courts will not require exhaustion of union remedies.

The courts have also refused to follow the rule where the action was for damages rather than reinstatement. Two reasons have been given for this: (1) a reversal of the decree of expulsion would not afford full redress for the injury to property rights and other damages suffered on account of expulsion, ${ }^{30}$ and (2) to hold otherwise would allow one of the parties to be arbiter of his own cause. ${ }^{31}$

Generally, the courts will apply the exhaustion rule only if they have otherwise decided not to give the plaintiff relief. ${ }^{32}$ Thus, although the courts consistently profess acceptance of the rule, based on the "contract" theory, they proceed to create an exception whenever they feel that the particular members' conduct should be privileged. The result is a body of law that will guide future courts about as well as a ship would be guided in a channel without buoys.

\section{Judicial Remedies}

Suppose a union member is expelled or suspended from his local and he applies directly to a court of equity for relief. The court decides, on the basis of one of the reasons previously discussed, that the member need not exhaust his remedies within the union. This means nothing to the disciplined member unless some remedy is provided which will protect his interests.

os Dragwa v. Federal Labor Union, 136 N.J.Eq. 172, 41 A.2d 32 (1945); Browne v. Hibbets, 25 N.Y.S.2d 573 (Sup.Ct. 1941); Gaestel v. Brotherhood of Painters, Decorators \& Paperhangers, 120 N.J.Eq. 358, 185 A. 36 (1936); Abdon v. Wallace, 95 Ind. App. 604, 165 N.E. 68 (1929).

20 Simons v. Berry, 240 N.Y. 463, 148 N.E. 636 (1925); Kunze v. Weber, 197 App. Div. 319, 188 N.Y.S. 644 (1st Dep't. 1921).

30 See, e.g., Smith v. International Printing, Pressmen \& Assistants' Union, 190 S.W.2d 769 (Tex.Civ.App. 1945) ; Grand Int'l. Brotherhood of Locomotive Engineers v. Green, 210 Ala. 496, 98 So. 569 (1923); St. Louis \& S.W. Ry. Co. of Texas v. Thompson, 102 Tex. 89, 113 S.W. 144 (1908).

31 See Brotherhood of R. Trainmen v. Barnhill, 214 Ala. 565, 108 So. 456 (1926).

s2 Summers, op. eit. supra note 11, at 1093 . 
A union member has four substantial interests which may be involved in expulsion from his union: (1) the right to continue working in spite of a union security provision; (2) the right to participate in union activities; (3) the right to receive benefit payments; (4) the right to damages for injuries and indignities suffered in the past..$^{33}$ An inquiry into the nature of the remedies available and their effectiveness to protect these interests is imperative.

Usually the disciplined member will bring an action in equity for reinstatement, and if the court of equity finds that there has been an improper expulsion or suspension, it will, by mandatory injunction or otherwise, compel the reinstatement of the wrongfully expelled or suspended member. ${ }^{34}$ This remedy entitles him to receive insurance benefits and to work under a union security clause, as well as to participate fully in union activities.

Although it has been uniformly held in labor union cases that mandamus is a proper remedy to restore one improperly expelled or suspended from an incorporated labor union, ${ }^{35}$ it has been held that this remedy does not lie against a voluntary unincorporated association..$^{36}$ However, later cases have held that mandamus is a proper remedy of one expelled from a labor union even though the union may not be incorporated. ${ }^{37}$ And some jurisdictions have adopted this rule by statute. ${ }^{38}$

In addition to a suit for reinstatement, either by an equitable action or by a writ of mandamus, one unlawfully

Summers, op. cit. supra note 11, at 1093 .

34 See OAKEs, Organized Labor and Industrial Oonflicts, sec. 65 at 72 (1927).

$\approx$ People ex rel. Holmstrom v. Independent Dock Builders' Benev. Un. ion, 164 App. Div. 267, 149 N.Y.S. 771 (1st Dep't. 1914); O'Brien v. Mnsical Mutual Protective \& Benev. Union, 64 N.J.Eq. 525, 54 A. 150 (1903).

so People ex rel. Shults v. Love, 199 App. Div. 815, 192 N.Y.S. 354 (1st Dep't. 1922); Jersey City Printing Co. v. Cassidy, 63 N.J.Eq. 759, 53 Atl. 230 (1902); Holmes v. Brown, 146 Ga. 402, 91 S.E. 408 (1917).

st Smetherham v. Laundry Workers' Union, Local No. 75, 44 Cal. App.2d 131, 111 P.2d 948 (1941); Elevator Operators \& Starters' Union, Local 117, of San Francisco v. Newman, 180 P.2d 42, 44 (Calif. 1947).

se see, e.g., Nissen v. International Brotherhood of Teamsters, Chauffeurs, Stablemen \& Helpers of America, 229 Iowa 1028, 295 N.W. 858 (1944); Petri v. Ruehl, 22 N.Y.S.2d 549 (Sup.Ct. 1940). 
suspended or expelled from a union, may sue for the damages thereby occasioned. ${ }^{39}$ The damages recoverable may include wages lost by discharge, ${ }^{40}$ or from inability of the expelled member to secure employment at his trade. ${ }^{41} \mathrm{Re}-$ covery is limited to the difference between the amount he would have earned at his trade, and that which he actually earned or could have earned had he sought equivalent employment. ${ }^{42}$ Although he is bound to take equivalent employment, he is not bound to go to another city to look for work.43 Damages may also include such sums as will compensate him for mental suffering or humiliation. ${ }^{44}$ It has also been held that an appeal to a higher tribunal in a union from an order of suspension and fine does not amount to a waiver of damages resulting from the action of the union in procuring a member's discharge from employment by a threat to strike. ${ }^{45}$

It has been held that an action against an unincorporated union which allegedly expelled members improperly, for damages to recompense for periods of consequent unemployment, may be maintained despite the contention of the union that the association is not liable unless all the members can be shown to be liable. ${ }^{46}$ However, in many states the union cannot be held liable for the acts of its members or its officers unless the membership as a whole has approved or consented to the improper expulsion or suspen-

so OAKEs, op. cit. supra note 34 , sec. 69 at 77 .

10 Fleming $\nabla$. Moving Picture Machine Operators of Essex County, 16 N.J. 502, 1 A.2d 850 (1938).

1 Stenzel v. Cavanaugh, 189 N.Y.S. 883 (Sup.Ct. 1921).

a Johnson $\nabla$. International of the United Brotherhood of Carpenters \& Joiners, 54 Nev. 332, 16 P.2d 658 (1932).

4s Connell v. Stalker, 21 Misc. 609, 48 N.Y.S. 77 (Sup.Ct. 1897).

4 Nissen v. International Brotherhood of Teamsters, Chauffeurs, Stablemen \& Helpers of America, 229 Iowa 1028, 295 N.W. 858 (1941); St. Louis \& S.W. Ry. Co. of Texas V. Thompson, 102 Tex. 89, 113 S.W. 144, 19 Ann. Cas. 1250 (1908).

* Blanchard ₹. Newark Joint Dist. Council, 77 N.J.L. 389, 71 A. 1131 (1909). See St. Louis \& S.W. Ry. Co. of Texas v. Thompson, supra note 44, for the proposition that exemplary damages are recoverable against persons who are actuated by malice in procuring the member to be expelled.

"6 Glauber v. Patoff, 15 Lab. Rel. Ref. Rep. 948 (N.Y.Sup.Ct. 1944). 
sion. ${ }^{47}$ This rule unjustly prevents recovery from the union treasury except in rare cases, although the officers were clearly acting in their official capacity as agents of the union. To permit the disciplined member to sue the officers for the damages resulting from the improper expulsion or suspension is of little value because the officers may own little property in their own name.

\section{Weaknesses of Jndicial Remedies}

It is at once apparent that the present judicial remedies are hardly adequate. In a given case the court may require the disciplined member to first exhaust all his remedies within the union and hence a court action for reinstatement may come too late to be of much value. During the appeal period within the union, which may often be a very long time, ${ }^{48}$ the disciplined member is being deprived of current income and his right to participate in the formulation of union policy.

Court actions are, in most cases, too expensive and an appeal is, financially speaking, usually out of the question. The union on the other hand, with its greater resources, can carry the case through the courts for a very long time. Even though the expelled member has obtained judgment, the award of damages may be worthless if the court applies the rule that the membership as a whole must have approved or consented to the wrongful discipline.

The courts could correct these weaknesses to some extent by giving interim protection to the disciplined member pending his appeal within the union, e.g., by prohibiting his discharge under a union security clause until the final appeal has been heard. Financial obstacles could be removed through legislation providing for an agency to act as a public prosecutor, by permitting recovery of multiple damages, by including attorney's fees in the measure of damages and by permitting recovery of damages out of the union treasury. ${ }^{49}$

4 Browne v. Hibbets, 25 N.Y.S.2d 573 (Sup.Ct. 1941); People ex rel. Solomon v. Brotherhood of Painters, 218 N.Y. 115, 112 N.Đ. 752 (1916).

ss See note 25 supra.

so Summers, op. cit. supra note 11, at 1096. 


\section{Remedies Under Taft-Hartley}

Under Section 8(a) (3) (B) of the Taft-Hartley Act,50 it would be an unfair labor practice for an employer to discharge an employee under a union security clause for reasons other than the failure of the employee to tender the periodic dues and the initiation fees uniformly required as a condition of acquiring or retaining membership. Under Section 8(b) (2) of the Act, it is an unfair labor practice for the union to cause an employer to discriminate against an employee in violation of Section 8(a) (3) (B).

However, the Taft-Hartley Act has not gone far enough in one direction; i.e., it only protects the disciplined member's right to work. And it has gone too far in the other direction; i.e., it unduly restricts the union in its control over its membership. As in the case of a direct action for reinstatement, there is lacking in Taft-Hartley any provision for interim relief and it may be months before the Board can act on a particular case of union disciplinary abuse. ${ }^{51}$ The disciplined member is somewhat aided by Section 301 (b) of the Act, since by this section he can sue the union for damages. However, he must still rely for reinstatement on the judicial remedy, the inadequacies of which remain unaffected.

\section{Conclusion}

Of an estimated total of 14.8 million workers covered by written agreements in 1946, over 11 million, or $78 \%$, were working under union-security provisions which in one form or another required union membership as a condition of hiring or continued employment, or both. ${ }^{52}$ Thus union membership is a prerequisite to earning a living in many fields. In view of this situation, the doctrine of exhaustion

\footnotetext{
to The Labor Management Relations Act of 1947, as amended, 61 Stat. 140, 141, 29 U.S.C.A. sec. 158(a) (3), 158(b) (2) (Supp. 1951).

G In a Bill to Amend the Taft-Hartley Act of 1947 , submitted by the American Civil Liberties Union, covering all phases of internal union democracy, it was proposed the enforcement of the legislation could best be lodged not in the courts, but in the National Labor Relations Board, with authority to prosecute violations as unfair labor practices. The bill was never accepted.
}

63 U.S. Dep'T. Labor, Bur.Lab.Sta'T., BULL. 908 (1947). 
of remedies does not adequately protect the rights of the individual worker.

In many instances the disciplinary procedure of the union, which is a quasi-judicial process, does not meet even the most essential requirements of an ordinary judicial proceeding, i.e., notice of the charges and a fair hearing; nor does a court order generally redress the whole wrong once the court has been persuaded to take jurisdiction. To promote substantial justice it is imperative that union disciplinary procedure should be analogous to that observed in ordinary judicial proceedings. ${ }^{53}$ The courts should hold the union to greater exactness in its statement of the rules governing expellable offenses, and the appellate procedure within the union should be required to comply with certain minimum standards respecting effectiveness, certainty, and promptness..$^{54}$

The doctrine of exhaustion of remedies was borrowed from the older laws of voluntary associations and applied to labor unions. ${ }^{55}$ This of course is unjustified. Labor unions, other voluntary associations, and the courts assert that the purpose behind the doctrine of exhaustion of remedies is control of membership. However, the validity of the rule does not carry over to unions which have ceased to be voluntary. To compare a labor union with an ordinary voluntary association or fraternal order is to shun the realities of the situation. With the tremendous growth of centralized union administration and its concomitant risk of misuse of disciplinary power, ${ }^{56}$ this borrowing from the older

\footnotetext{
cs See Gallagher v. Monaghan, 58 N.Y.S.2d 618 (Sup.Ct. 1945); Coleman v. O'Leary, 58 N.Y.S.2d 812 (Sup.Ct. 1945).

st See Leo v. Local Union No. 612, 126 Wash. Dec. 466, 174 P.2d 523 (1946) for an example showing a step toward holding the union to greater exactness in its statement of the rules governing expellable offenses. The Washington court found that even if the charge against the plaintiff, of solfciting membership for another union from among defendant's members, were true, the offense did not come within the expellable offenses set out in the constitution, such as creating dissension among members, destroyiug the interest and harmony of the local union, or seeking to dissolve the local union.

*6 Gallagher v. Monaghan, supra at note 53.

to Shister, op. cit. supra note 2, at 94.
} 
law of voluntary associations no longer has any merit, and should be abandoned.

By applying the doctrine of exhaustion of remedies with its multifarious exceptions, there has been evolved a thoroughly confusing field of law. Perhaps the situation might be most effectively ameliorated if the legislature created special labor tribunals composed of specialists in the field of labor relations, with authority to review cases of expulsion and suspension of union members. These special labor tribunals could lay down criteria which would help the union maintain group solidarity and efficient administration, and at the same time insure to the members of the union a maximum freedom of expression and action. 